Article

\title{
The Edge Effect on Plant Diversity and Soil Properties in Abandoned Fields Targeted for Ecological Restoration
}

\author{
Sheunesu Ruwanza \\ Department of Environmental Science, Rhodes University, Grahamstown 6140, South Africa; \\ ruwanza@yahoo.com; Tel.: +27-46-603-7009
}

Received: 11 September 2018; Accepted: 30 November 2018; Published: 28 December 2018

\begin{abstract}
Changes in biotic and abiotic factors may create opportunities for biodiversity recovery in abandoned agricultural fields. This study examined the natural/old field edge effect on plant diversity and soil properties at Lapalala Wilderness in Limpopo Province, South Africa. Detailed vegetation surveys and soil measurements were conducted in three old fields that share a natural/old field road edge boundary. On each site, three transects, each with four plots $(10 \times 10 \mathrm{~m})$, located $10 \mathrm{~m}$ into the natural area and 10,30 and $50 \mathrm{~m}$ into the old field from the edge, were setup. Plant diversity and composition measurements were conducted on each plot. Soil moisture and total N, C and P were measured at the center of each plot. Results indicate that abundance of some woody species was significantly $(P<0.001)$ higher close to the edge than far into the old fields. However, this was not the case for herbs and grasses which did not increase with edge proximity. All measured soil properties were significantly $(P<0.001)$ higher close to the edge than far into the old fields. The study concludes that both vegetation and soil properties are influenced by proximity to the edge.
\end{abstract}

Keywords: old field succession; tree establishment; microclimate; plant-soil interactions; soil nutrients; Lapalala Wilderness

\section{Introduction}

Land abandonment has been on the rise in South Africa due to several factors, such as rural depopulation, poor land management, shifts in global markets for agricultural products and decline in soil fertility [1,2]. A recent survey showed that abandonment of cropland in South Africa was widespread between 1950 and 2010, with peak abandonment rates occurring between 1970 and 1990 [2]. In view of the high land abandonment rates in the country, ecological restoration of abandoned agricultural fields (here after referred to as old fields) is very important due to direct and indirect ecological benefits associated with restored ecosystems [3-5]. Restored old fields improve the flow of ecosystem services by conserving and improving natural capital, soil stability, water quality, biodiversity, and global climate stability [6]. From an economic stand point, restored old fields create employment through ecotourism [6,7]. However, the successful recovery of vegetation and soil in old fields is determined by the interaction of several biotic and abiotic factors e.g., soil seed bank, seed dispersal mechanisms, propagule source, species interactions, soil nutrient availability and temperature regimes [8,9]. To further complicate the restoration process in old fields, the extent to which both vegetation and soil properties were damaged during cultivation, has a bearing on the recovery process [4]. For example, cultivation has been shown to negatively affect soil nutrients and soil stored seed banks $[4,8,10]$, and the extent to which the above-mentioned soil properties are damaged may slow down the natural succession process after the land is abandoned. 
Recent studies have shown that vegetation and soil recovery in old fields can be affected by proximity to forest edge [5,11,12]. The edge effect is defined as the difference in biotic and abiotic factors that exist at the border of a fragmented habitat relative to the interior environment $[12,13]$. Increased seed dispersal rates and the creation of microclimates at the natural/old field edge have been reported to favor establishment of plant communities that are different from those found in the old field interior $[5,10,14]$. Some studies have shown that proximity to the natural/old field edge facilitates the establishment of woody species over other growth forms $[10,15,16]$. In contrast, some studies have concluded that the edge effect does not influence vegetation recovery in degraded ecosystems [17-19]. Given the mixed results on how edge proximity affects vegetation, there exist a need to assess the edge effect across a variety of environments to develop predictive hypotheses across varying contexts.

Few studies have looked at the edge effect on soil properties in old fields targeted for ecological restoration [5]. Bueno et al. [5] and Ramirez et al. [20] reported that creation of conducive soil microclimates underneath the canopy of recruiting plants can facilitate germination and growth of more plants at the edge. Recruiting plants can in turn exert a facilitative effect through litter accumulation and creation of suitable conditions for litter decomposition, thus subsequently increase soil nutrients $[5,21]$. In old fields where the edge has a positive effect on vegetation abundance and diversity, there exists a hypothesis that soil properties will also be positively affected by edge proximity, which is likely due to vegetation changes [5]. This has never been tested in old fields of savanna bushveld were ecological restoration initiatives are taking place at Lapalala Wilderness. To make recommendations for ecological restorations in old fields targeted for ecological restoration at Lapalala Wilderness, this study examined how natural/old field edges affect both plant diversity and soil properties. The main research question was: does proximity to natural/old field edges affect plant (species diversity and composition) and soil properties (soil moisture and macronutrients of N, C, and $\mathrm{P}$ ). The study hypothesis is that changes in vegetation diversity and cover due to edge proximity will influence changes in soil properties. The results are intended to guide future soil and vegetation recovery studies in old fields targeted for ecological restoration in South African ecosystems.

\section{Materials and Methods}

\subsection{Study Area}

The study was conducted at Lapalala Wilderness reserve, which is in Limpopo Province, South Africa (Figure 1). The privately-owned reserve is approximately 45,000 ha and is home to several wild animals e.g., white rhinoceros, zebra, impala, wildebeest, giraffe and kudu. Mucina and Rutherford [22] classified vegetation in the reserve as Waterberg Mountain Bushveld. Although soils in the reserve are predominantly sandy from the Waterberg groups, the old fields where the study was conducted are dominated by clay and loam soils from basic norite/epidiorite substrates [22,23]. A recent study at the same study site showed that soils are generally acidic with an average $\mathrm{pH}$ of 4.73 [23]. Annual average rainfall ranges from 400 to $600 \mathrm{~mm}$ and most rain falls in summer between September and April. Temperatures are hot in summer (maximum $30^{\circ} \mathrm{C}$ in January) and cold in winter (minimum $4{ }^{\circ} \mathrm{C}$ winter). Winter months commonly have frost, averaging 61 to 90 days annually. Mean annual evaporation ranges between 2200 to $2400 \mathrm{~mm}[22,24]$. 


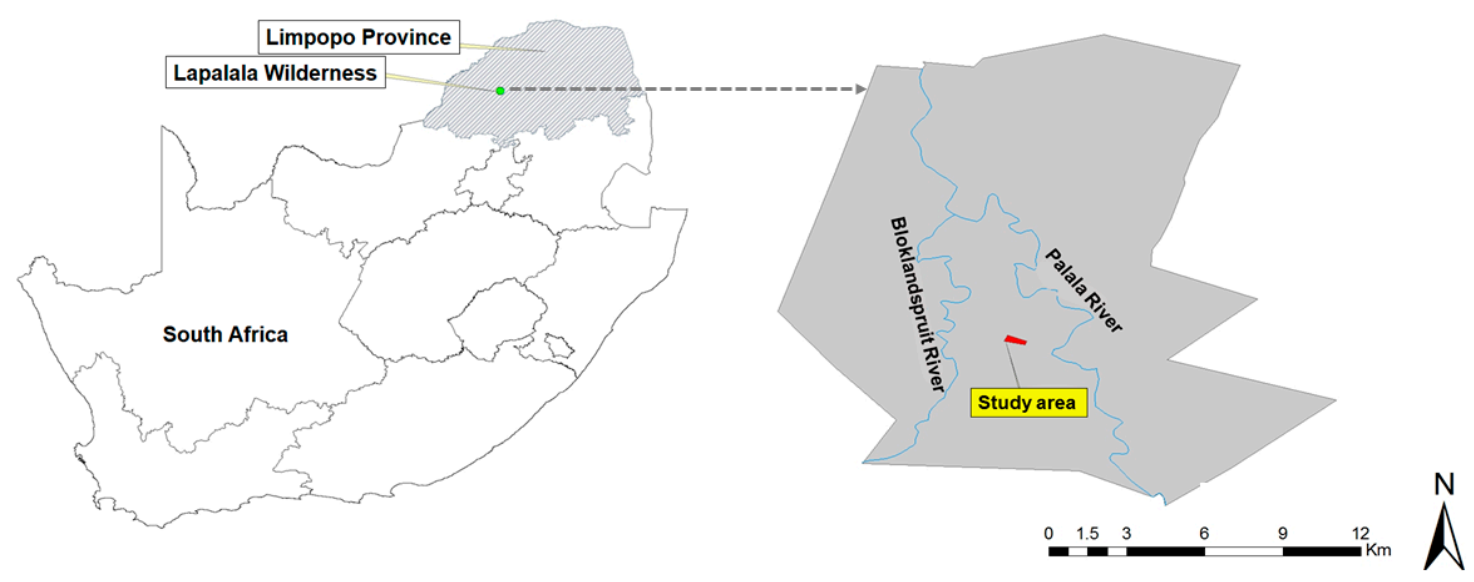

Figure 1. Location of the study area at Lapalala Wilderness, Limpopo province of South Africa.

\subsection{Sampling Design}

Three old field sites that share a farm road border with natural sites were identified towards the end of the rainy season (April 2017) to optimize plant identification. The three sites were approximately $300 \mathrm{~m}$ apart to allow independence of measurements [25]. The 35-year old fields were previously used for tobacco farming but are currently used for wild animal grazing. At each of the three sites, three line transects that were $20 \mathrm{~m}$ apart were setup (Figure 2). The line transects which run perpendicular to the farm road edge extended $10 \mathrm{~m}$ into the natural area and $50 \mathrm{~m}$ into the old field. At $10 \mathrm{~m}$ (from the road edge into the natural side), and at 10,30, and $50 \mathrm{~m}$ (from the road edge into the old fields) plots measuring $10 \mathrm{~m} \times 10 \mathrm{~m}$ were setup for plant and soil measurements.

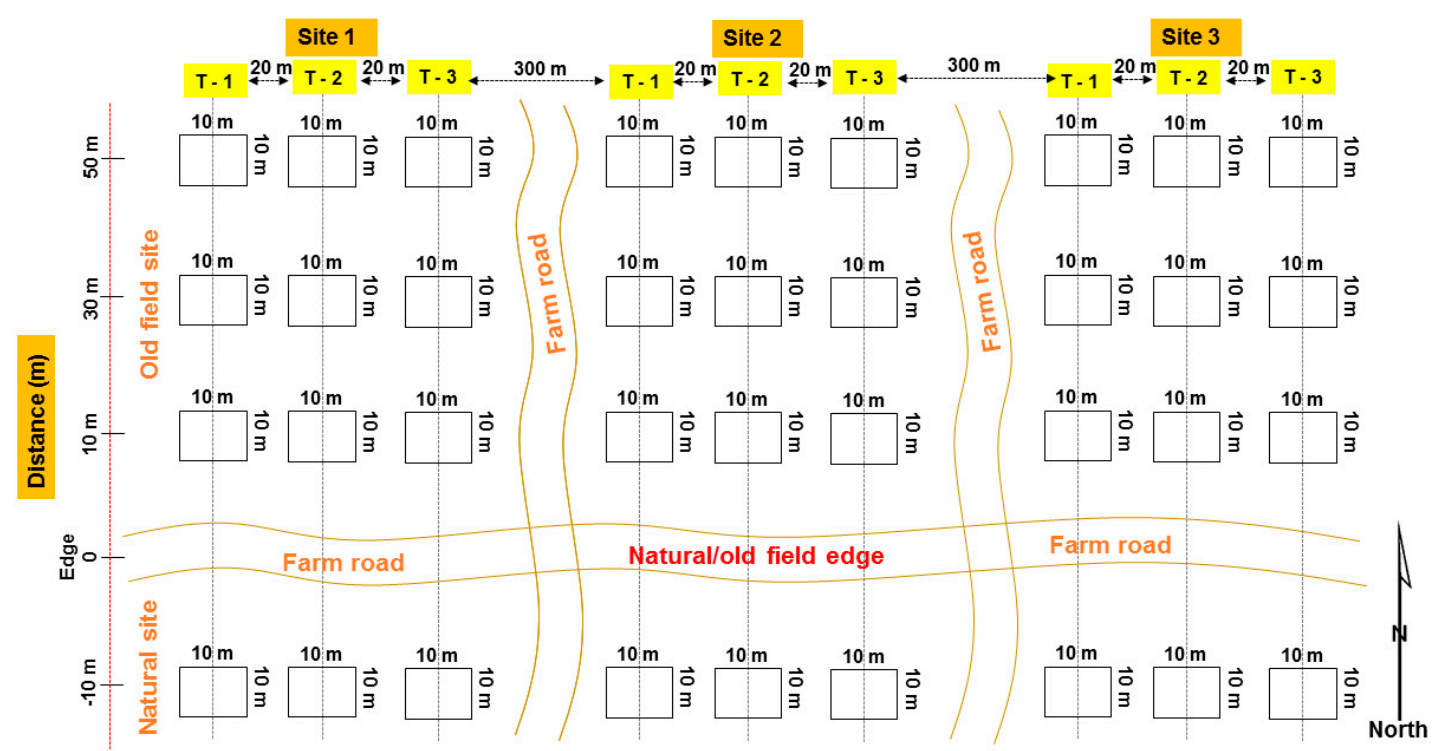

Figure 2. Schematic diagram showing the three sites, transects (T-1, T-2 and T-3) and sampled plots at various distances $(-10 \mathrm{~m}, 10 \mathrm{~m}, 30 \mathrm{~m}$, and $50 \mathrm{~m})$ from the natural/old field edge.

\subsection{Vegetation Surveys}

Within each plot, a detailed vegetation survey was conducted in April (end of summer). Conducting vegetation surveys during April allowed easily identification of plant species. Plant species richness and abundance of all trees and shrubs was determined by counting the species present in the $10 \mathrm{~m} \times 10 \mathrm{~m}$ plot. Species richness and abundance for herbs and grasses was determined by counting all the species present in a $1 \mathrm{~m} \times 1 \mathrm{~m}$ quadrate placed at the center of the plot. Given that some grasses and herbs are small and numerous, the above-mentioned quadrate size was used to allow 
accurate count and cover estimates for these two growth forms. Cover of all the plant species present in the plot were visually estimated to the nearest $5 \%$ and $1 \%$ when species occupied less than $5 \%$ of the plot. A sample of all the plant species present in the plot and quadrate was collected for identification at University of Venda in the Department of Botany herbarium. Plant species were assigned to four growth forms, namely trees, shrubs, herbs and grasses based on phytomorphology.

\subsection{Soil Sampling}

At the center of each plot, two soil cores (30 cm apart) were collected for total N, C and P measurements, using a soil core measuring $10 \mathrm{~cm}$ in diameter, at $8 \mathrm{~cm}$ depth. Soil cores were collected once due to limited finances and the expectation that there would not be any marked differences that would warrant repeated measures within a season. After collection, soils were sieved using a $2 \mathrm{~mm}$ sieve to remove stones and debris. Soils from the first collecting point were measured for gravimetric soil moisture, whilst soils from the second collecting point were measured for macronutrients of total N, C, and P. Gravimetric soil moisture was measured by first weighing the soils wet, oven drying them at $105^{\circ} \mathrm{C}$ for $72 \mathrm{~h}$, and then re-weighing them to obtain the water content, which was expressed as a percentage [26]. Total soil $\mathrm{N}$ was determined by complete combustion using an Elemental Analyser (EuroVector Euro EA 3000, Milan, Italy), whilst total soil C was determined using the Walkley-Black method [27]. Soil P was analysed using a Bray-2 extract [28].

\subsection{Statistical Analysis}

For each plot and quadrate, species richness, Shannon-Wiener $\left(\mathrm{H}^{\prime}\right)$, Simpson's index of diversity (1-D) $[29,30]$ and Evenness index (J) using Pielou's ' $J$ ' [31] were calculated. To avoid pseudo-replication, plant and soil results from the three transects per site and from the same distance from the edge were averaged [32]. Data were tested for normality and proof of homogeneity of variance using the Shapiro-Wilk's and Levene's test, respectively, and data were normally distributed. To examine the effects of edge on measured plant and soil variables, one-way ANOVA was performed in Statistica version 13.1 [33]. Correspondence analysis (CA) was performed using Canoco for Windows 5 [34] to investigate how distance from the edge affected the plant species assemblage. Plant species abundance data were log-transformed before CA was performed to eliminate the influence of extreme values on ordination scores.

\section{Results}

\subsection{The Edge Effect on Vegetation}

Species richness and Shannon-Wiener showed significant $(P<0.01)$ differences between the measured distances from the natural/old field edge (Figure $3 a, b)$. Species richness was significantly $(P<0.001)$ higher at $10 \mathrm{~m}$ from the edge into the natural area compared to all other measured distances into the old fields. However, comparisons between distances from the edge into the old fields on species richness showed no significant $(P>0.05)$ differences (Figure 3a). Shannon-Wiener was significantly $(P<0.01)$ higher at $10 \mathrm{~m}$ from the edge of both the natural and old field, compared to $30 \mathrm{~m}$ and $50 \mathrm{~m}$ into the old fields (Figure $3 b$ ). Comparisons on Shannon-Wiener between distances from the edge into the old field showed no significant $(P>0.05)$ differences (Figure $3 b)$. Both evenness and Simpsons index of diversity showed no significant $(P>0.05)$ differences at measured distances from the edge (Figure 3c,d). 

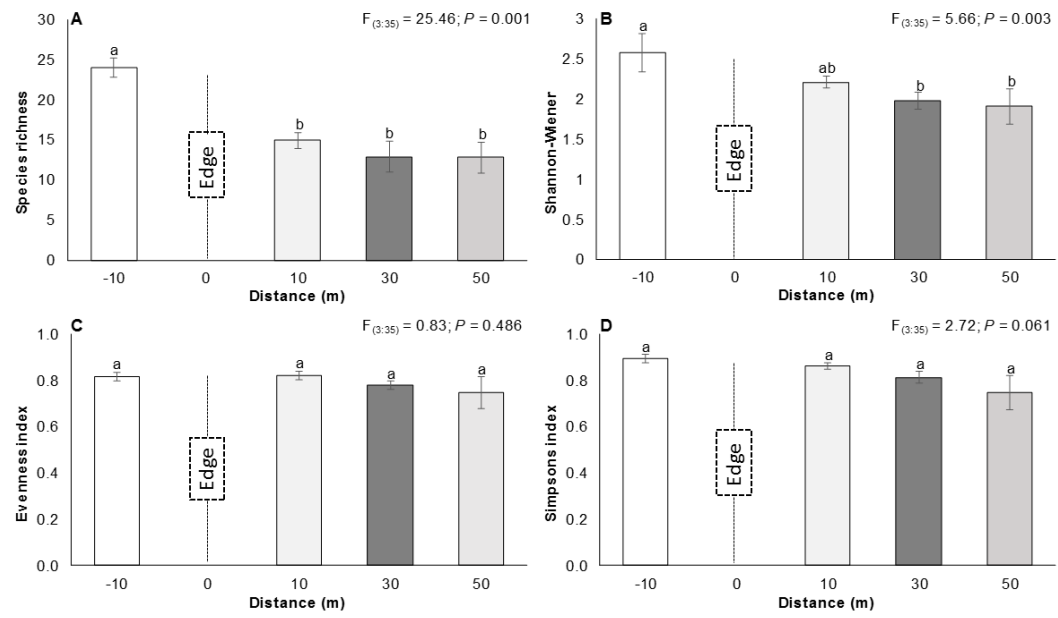

Figure 3. Comparison of indices of diversity (a-species richness, $\mathbf{b}-$ Shannon-Wiener, $\mathbf{c}$ - evenness index and $\mathbf{d}-$ Simpsons index) at various sampling distance from the natural/old field edge. Data are means $\pm \mathrm{SE}$ and significant ANOVA results are shown.

Species richness for trees and shrubs significantly $(P<0.001)$ decreased with distance from the edge into the old field (Figure 4a). Species richness for herbs significantly $(P<0.05)$ increased with distance from the edge, but there were no significant $(P>0.05)$ differences between $10 \mathrm{~m}$ into the natural areas compared to 30 and $50 \mathrm{~m}$ into the old field (Figure $4 \mathrm{~b}$ ). Species richness for grasses significantly $(P<0.001)$ increased with distance from edge into the old field (Figure $4 \mathrm{c})$. Cover of trees and shrubs significantly $(P<0.001)$ decreased with increase in distance from the edge (Figure $4 \mathrm{~d})$. Cover for herbs was significantly $(P<0.05)$ higher at $50 \mathrm{~m}$ compared to $10 \mathrm{~m}$ from the edge into the old field. Comparisons of the cover of herbs between $10 \mathrm{~m}$ into natural areas and $30 \mathrm{~m}$ into the old fields showed no significant $(P>0.05)$ differences (Figure $4 \mathrm{e})$. Cover for grasses significantly $(P<0.001)$ increased with an increase in distance from the edge (Figure 4f).
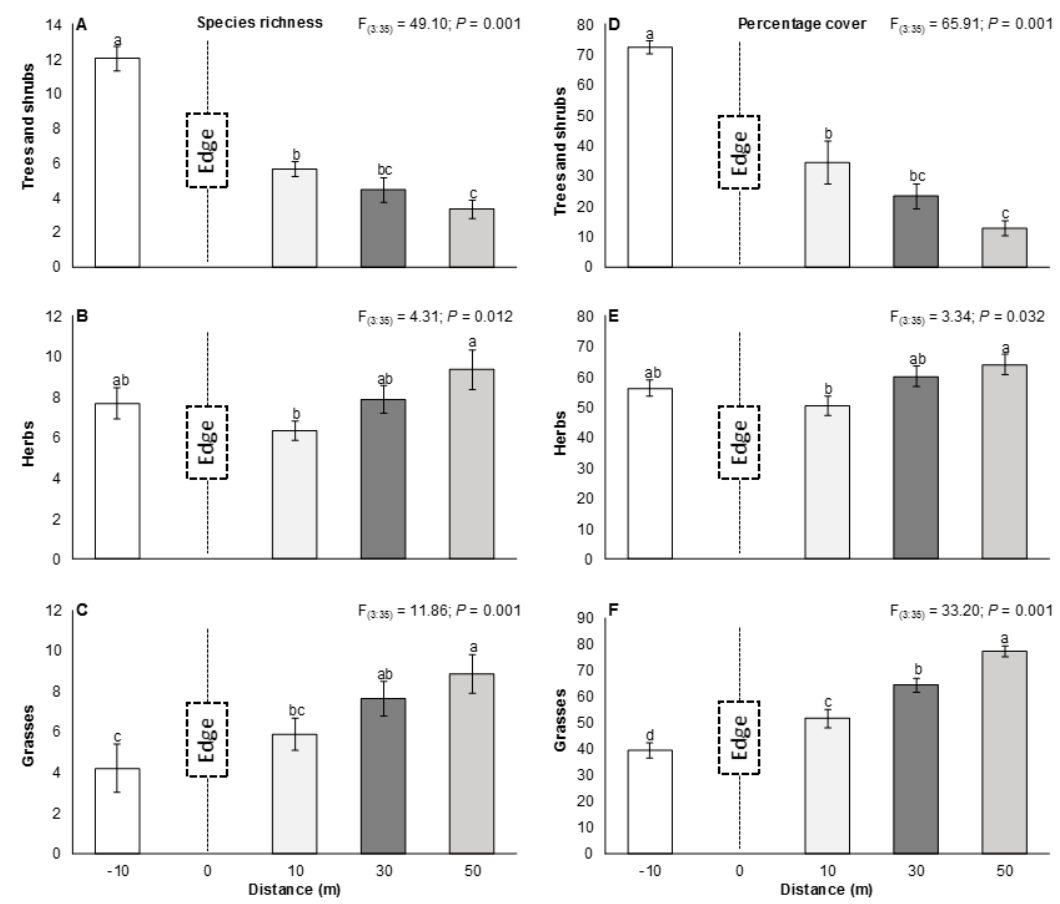

Figure 4. Comparison of species richness (A-C) and vegetation cover (D-F) for trees and shrubs, herbs, and grasses at various sampling distance from the natural/old field edge. Data are means $\pm \mathrm{SE}$ and significant ANOVA results are shown. 
A list of the 36 plant species that were identified at various distances from the natural/old field edge are presented in the Appendix A (Table A1), with their occupancy frequencies shown. Correspondence analysis for trees and shrubs showed that most species assembled in the natural areas, $10 \mathrm{~m}$ from the edge (Figure 5a). However, the woody species of Peltophorum africanum, Senegalia nigrescens, S. senegal, Vachellia tortilis, V. nilotica, V. karroo, and Lippia javanica appeared at all measured distances from the edge, but their occupancy frequencies in the old fields decreased with an increase in distance from the edge (Figure 5a). Correspondence analysis for herbs showed that the species Felicia $s p$ dominated $10 \mathrm{~m}$ into the natural area from the edge, whereas Solanum panduriforme and S. incanum dominated $10 \mathrm{~m}$ into the old field. The herb species of Xerochrysum bracteatum, Gomphrena celosioides and Datura stramonium assembled $30 \mathrm{~m}$ and $50 \mathrm{~m}$ into the old field from the edge (Figure 5b). Correspondence analysis for grasses showed only two distinct groups, where Aristida congesta, Digitaria eriantha and Eragrostis inamoena assembled $10 \mathrm{~m}$ into the old field from the edge and Panicum maximum, Cynodon dactylon and Eragrostis lehmanniana assembled $30 \mathrm{~m}$ and $50 \mathrm{~m}$ into the old field as well as $10 \mathrm{~m}$ into the natural area from the edge (Figure 5c).
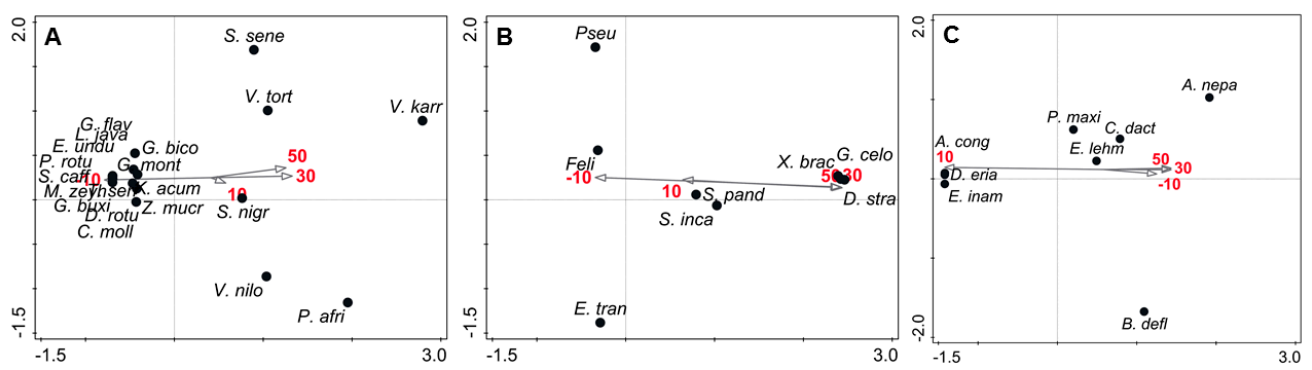

Figure 5. Correspondence analysis (CA) ordination of species $(\bullet)$ along sampled distance from the natural/old field edge for (a) trees and shrubs, (b) herbs, and (c) grasses. The first four letters of the species names are presented with full names in the Appendix A (Table A1).

\subsection{The Edge Effect on Soils}

Generally, measured soil parameters decreased with an increase in distance from the edge into the old fields. Gravimetric soil moisture was significantly $(P<0.001)$ higher $10 \mathrm{~m}$ into both the natural and old fields from the edge compared to 30 and $50 \mathrm{~m}$ into the old field from the edge (Figure 6a). All measured soil macro nutrients of total $\mathrm{N}, \mathrm{C}$ and $\mathrm{P}$ significantly $(P<0.001)$ decreased with an increase in distance from the edge into the old fields (Figure $6 \mathrm{a}-\mathrm{d}$ ). However, for soil $\mathrm{C}$ and $\mathrm{P}$, there were no significant $(P>0.05)$ differences at 30 and $50 \mathrm{~m}$ distances from the edge into the old fields (Figure $6 c, d)$.
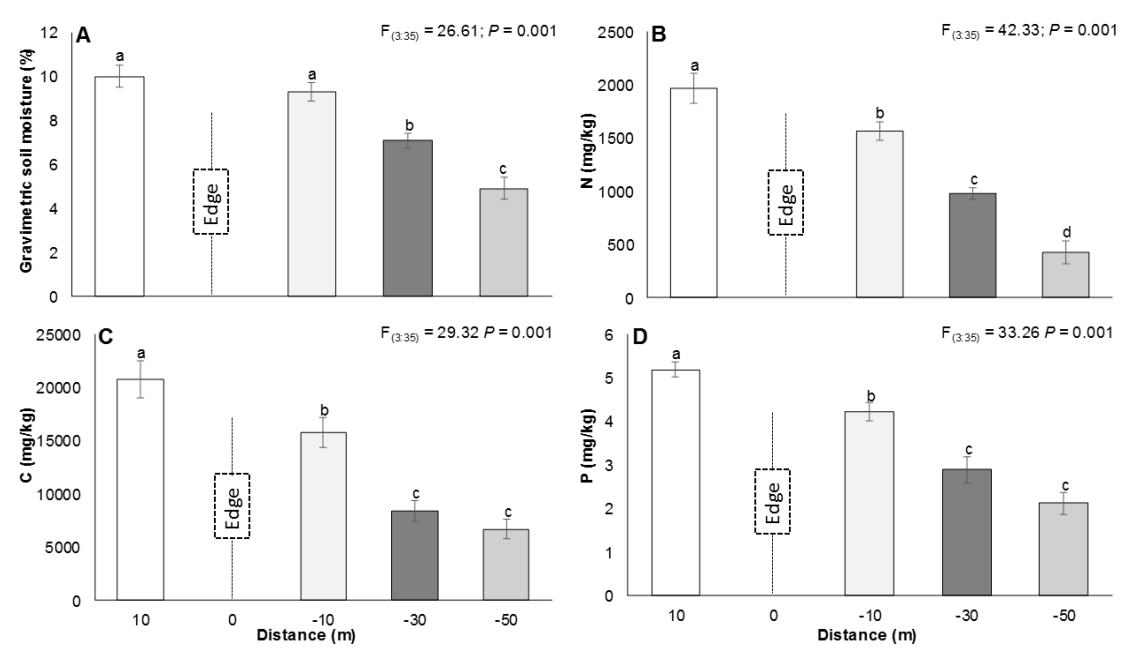

Figure 6. Comparison of soil moisture, soil N, soil C and soil $\mathrm{P}$ at various sampling distance from the natural/old field edge. Data are means $\pm \mathrm{SE}$ and significant ANOVA results are shown. 


\section{Discussion}

\subsection{The Edge Effect on Vegetation}

Results of this study indicate that the edge effect can influence plants in degraded old fields at Lapalala Wilderness. This is because species richness and cover of some woody species e.g., P. africanum, S. nigrescens, S. Senegal, V. tortilis, V. nilotica, and V. karroo decreased with increasing distance from the edge into the old field. The above results concur with previous studies that have shown that the establishment of woody species in degraded old fields is strongly influenced by proximity to natural edge areas $[5,10,15,35,36]$. However, some studies have shown the opposite, where species richness and composition do not respond to the edge effect [17-19]. One of the factors that could explain the reported high abundance of some woody species closer to the old field edge, is increased seed dispersal in areas close to the edge (this is regarded as the concept of proximity to seed source). Previous studies have shown that proximity to seed sources is linked with increased seed dispersal and plant establishment near the edge as compared to far from the edge [37,38]. A study by Cubina and Aide [39] showed that both seed rain and soil seed bank are higher near the seed source and tend to decrease with increasing distance from the source. For example, Krug and Krug [40] reported that seed density of native species was closely related to distance from the natural vegetation boundary. In another study linked to seed dispersal, Donaldson et al. [41] showed that pollination rates are higher close to the natural edge and decrease with distance from the edge boundary. This indicates that a higher number of pollinators are found near the source (natural forested area) as compared to far from the source, this is likely to contribute to variations in seed availability between areas close to the edge and those that are far.

The role of animal grazing on seed dispersal along the natural/old field edges was not tested in this study, though it could explain this study's observation on plant diversity. The dominance of animal grazing on edge boundaries is viewed as an animal safety measure because animals can retreat into the closed canopy natural vegetation for safety from predators [42-44]. This grazing behavior (commonly referred to as herbivore-predator avoidance strategy) will leave areas close to the edge being heavily grazed of grasses and herbs, compared to those far from the edge which become under grazed. Besides grazing, competitive interactions between plant species as well as edge size could also explain the observed effects of edge proximity on species composition [45]. Competition for resources (e.g., water) by woody species has the potential to negatively affect germination and establishment of grasses and herbs as compared to trees, this following results by [45] who showed that trees do suppress grass species growth through competition, though this is more common in wet compared to dry ecosystems. The size of the edge is known to affect seed dispersal [46,47], particularly animal movement between the natural and old field areas. For example, if the edge size is wide and open, some seed dispersers (e.g., ants) might avoid edge crossing due to predation fears [46].

\subsection{The Edge Effect on Soil}

Results of the study showed that soil moisture and nutrients of N, C, and P were high close to the edge as compared to far from the edge. Piessens et al. [48] reported varied effects of the edge on soil nutrients with such effects being limited to approximately $8 \mathrm{~m}$ from the edge. Riedel and Epstein [10] showed that soil carbon did not increase with proximity to the forest edge, suggesting that soil carbon is not influenced by the edge. In this study, the reported changes in soil properties in relation to distance from the edge could be a result of the creation of microclimatic conditions by recruiting woody species at the edge as compared to far from the edge. Previous studies have shown that soil temperature, which subsequently affects soil moisture and bacterial activities, is lower near the forest edge compared to far into the old field [49]. This points to the creation of favorable microclimates near the forest edge compared to far from the edge [50]. For example, increased vegetation abundance and diversity (in this case woody species) near the edge, has the potential to increase soil moisture content through plant canopy shading [51,52]. Similarly, increased vegetation abundance and diversity 
near the edge has the potential to increase litter fall and composition. Under favorable soil moist conditions created by the woody plants, increased bacterial and fungal activity will result in increased litter decomposition, thus increased soil nutrient content in moist areas near the edge compared to dry areas far from the edge.

The observed high species diversity for trees and shrubs and measured soil properties at the edge compared to far in the old field points to a positive plant-soil interaction [53,54]. A study by Normann et al. [47] concluded that changes in environmental and soil factors (e.g., soil pH and light penetration) at the edge might drive changes in species composition. Similarly, Wirth et al. [55] reported high soil chemical inputs at the edge, due to high litter deposition and decomposition, thus confirming the suspected positive plant-soil interaction. However, positive plant-soil interactions and feedbacks might lead to monodominance of some single species, thus leading to bush encroachment and plant invasion at the edge.

\section{Conclusions}

The hypothesis that changes in vegetation diversity and cover due to edge proximity will influence changes in soil properties is accepted. This is because results show that both vegetation diversity and measured soil properties decreased with increasing distance from the edge into the old field. Given the limited resources that ecological restoration initiatives receive, results of this study suggest that restoration initiatives should prioritize natural/old field edges. Prioritization can be in the form of fencing the edge (e.g., creating a $10 \mathrm{~m}$ buffer zone around the natural/old field edge) to facilitate vegetation and soil recovery. Fencing the edge has the potential to reduce animal grazing which could be causing substantial loss of grasses and herbs close to the edge. Secondly, if fencing the whole edge is expensive, protecting (through fencing) woody species that commonly occur at the edge e.g., P. africanum, S. nigrescens, S. Senegal, V. tortilis, V. nilotica, and V. karroo should be considered. The woody species recruiting at the edge have the potential to act as restoration foci, were vegetation and soil recovery is likely to start [56]. These plants can act as nurse plants, which have been shown to facilitate ecological restoration in degraded ecosystems [51]. Lastly, proximity to the natural/old field edge seems to be positively influencing vegetation (some woody plant species) and soil (moisture and macronutrients of N, C and P) recovery. The abundance and diversity of some woody species, as well as soil nutrient content, were higher near the natural/old field edge compared to far into the old field. However, to fully understand the edge effect on both plant and soil, it is important to conduct research on all the processes occurring at natural/old field edges e.g., seed dispersal, creation of microclimates, seed bank and plant establishment and growth.

Funding: This research received no external funding.

Acknowledgments: I am grateful to the owners, the managing director (Anton Walker), the conservation manager (Hermann Muller) and the research coordinator (Annemieke van der Goot) at Lapalala Wilderness for permission to conduct this study and for logistical help during field work.

Conflicts of Interest: The author declares no conflict of interest. 


\section{Appendix A}

Table A1. Thirty-six frequently occurring species in relation to distance from the natural/old field edge. ${ }^{*}$ ) Indicates that the species was present and is based on calculated species occupancy frequencies categorized as $*(1-20 \%),{ }^{* *}(21-40 \%),{ }^{* * *}(41-60 \%),{ }^{* * * *}(61-80 \%)$ and ${ }^{* * * * *}(81-100)$ with (-) indicating that the species was not present.

\begin{tabular}{|c|c|c|c|c|}
\hline \multirow{2}{*}{ Species Name } & \multicolumn{4}{|c|}{ Distance from Edge (in m) } \\
\hline & -10 & 10 & 30 & 50 \\
\hline \multicolumn{5}{|c|}{ Trees and Shrubs } \\
\hline Dombeya rotundifolia & $* * *$ & - & - & - \\
\hline Euclea undulata & $* * *$ & - & - & - \\
\hline Grewia monticola & $* * *$ & - & - & - \\
\hline Gymnosporia buxifolia & $* * *$ & - & - & - \\
\hline Kirkia acuminata & $* * *$ & - & - & - \\
\hline Mimusops zeyheri & $* * *$ & - & - & - \\
\hline Pterocarpus rotundifolius & $* * *$ & - & - & - \\
\hline Senegalia caffra & $* * *$ & - & - & - \\
\hline Peltophorum africanum & $* * *$ & $* *$ & ** & * \\
\hline Senegalia nigrescens & $* * * *$ & $* * *$ & * & * \\
\hline Senegalia senegal & $* * *$ & $* *$ & * & $*$ \\
\hline Vachellia tortilis & $* * *$ & $* * *$ & $* *$ & $* *$ \\
\hline Vachellia nilotica & $* * *$ & $* * *$ & $* *$ & $* *$ \\
\hline Vachellia karroo & $* * *$ & $* *$ & $* *$ & $*$ \\
\hline Combretum molle & $* * * *$ & $* *$ & - & - \\
\hline Ziziphus mucronata & $* * *$ & $* *$ & - & - \\
\hline Grewia bicolor & $* * *$ & $* *$ & - & - \\
\hline Grewia flava & $* * *$ & * & - & - \\
\hline Lippia javanica & $* * * *$ & * & * & $*$ \\
\hline Terminalia sericea & $* * * *$ & * & - & - \\
\hline \multicolumn{5}{|c|}{ Herbs } \\
\hline Gomphrena celosioides & - & $* * *$ & $* * *$ & $* * *$ \\
\hline Xerochrysum bracteatum & - & $* * *$ & $* * *$ & $* * *$ \\
\hline Solanum incanum & $* *$ & $* * * *$ & $* * *$ & $* * *$ \\
\hline Datura stramonium & - & $* * *$ & $* * * *$ & $* * *$ \\
\hline Solanum panduriforme & - & $* * *$ & - & - \\
\hline Emilia transvaalensis & $* *$ & $* * *$ & - & - \\
\hline Felicia $s p$ & $* *$ & $* * *$ & - & - \\
\hline Pseudognaphalium sp & $* *$ & $* * *$ & - & - \\
\hline \multicolumn{5}{|c|}{ Grasses } \\
\hline Arundinella nepalensis & * & $* * *$ & $* * * *$ & $* * * *$ \\
\hline Brachiaria deflexa & * & $* * * *$ & $* * *$ & $* * * *$ \\
\hline Cynodon dactylon & * & $* * * *$ & $* * *$ & $* * * *$ \\
\hline Panicum maximum & * & $* * * *$ & $* * *$ & $* * * *$ \\
\hline Eragrostis lehmanniana & * & $* * * *$ & $* * *$ & $* * * *$ \\
\hline Aristida congesta & - & $* * *$ & - & - \\
\hline Digitaria eriantha & - & $* * * *$ & - & - \\
\hline Eragrostis inamoena & - & $* * * *$ & - & - \\
\hline
\end{tabular}

\section{References}

1. De la Hey, M.; Beinart, W. Why have South African smallholders largely abandoned arable production in fields? A case study. J. S. Afr. Stud. 2017, 43, 753-770. [CrossRef]

2. Blair, D.; Shackleton, C.M.; Mograbi, P.J. Cropland abandonment in South African smallholder communal lands: Land cover change (1950-2010) and farmer perceptions of contributing factors. Land 2018, 7, 121. [CrossRef] 
3. Myster, R.W. Post-agricultural invasion, establishment, and growth of Neotropical trees. Bot. Rev. 2004, 70, 381-402. [CrossRef]

4. Cramer, V.A.; Hobbs, R.J.; Standish, R.J. What's new about old fields? Land abandonment and ecosystem assembly. Trends Ecol. Evol. 2008, 23, 104-112. [CrossRef] [PubMed]

5. Bueno, A.; Llamb, L.D. Facilitation and edge effects influence vegetation regeneration in old-fields at the tropical Andean forest line. Appl. Veg. Sci. 2015, 18, 613-623. [CrossRef]

6. Blignaut, J.; Aronson, J.; de Wit, M. The economics of restoration: Looking back and leaping forward. Ann. N. Y. Acad. Sci. 2014, 1322, 35-47. [CrossRef] [PubMed]

7. Barral, M.P.; Rey Benayas, J.M.; Meli, P.; Maceira, N.O. Quantifying the impacts of ecological restoration on biodiversity and ecosystem services in agroecosystems: A global meta-analysis. Agric. Ecosyst. Environ. 2015, 202, 223-231. [CrossRef]

8. Guariguata, M.R.; Ostertag, R. Neotropical secondary forest succession: Changes in structural and functional characteristics. For. Ecol. Manag. 2001, 148, 185-206. [CrossRef]

9. Ruwanza, S. Furrows as centers of restoration in old fields of Renosterveld, South Africa. Ecol. Restor. 2017, 35, 289-291. [CrossRef]

10. Riedel, S.M.; Epstein, H.E. Edge effects on vegetation and soils in a Virginia old-field. Plant Soil 2005, 270, 13-22. [CrossRef]

11. Ries, L.; Fletcher, R.J.J.; Battin, J.; Sisk, T.D. Ecological responses to habitat edges: Mechanisms, models, and variability explained. Annu. Rev. Ecol. Evol. Syst. 2004, 35, 491-522. [CrossRef]

12. Lin, L.; Cao, M. Edge effects on soil seed banks and understory vegetation in subtropical and tropical forests in Yunnan, SW China. For. Ecol. Manag. 2009, 257, 1344-1352. [CrossRef]

13. Murcia, C. Edge effects in fragmented forests: Implications for conservation. Trends Ecol. Evol. 1995, 10, 58-62. [CrossRef]

14. Gehlhausen, S.M.; Schwartz, M.W.; Augspurger, C.K. Vegetation and microclimatic edge effects in two mixed-mesophytic forest fragments. Plant Ecol. 2000, 147, 21-35. [CrossRef]

15. Smit, R.; Olff, H. Woody species colonization in relation to habitat productivity. Plant Ecol. 1998, 139, $203-209$. [CrossRef]

16. Meiners, S.J.; Pickett, S.T.A.; Handel, S.N. Probability of tree seedling establishment changes across a forest-old field edge gradient. Am. J. Bot. 2002, 89, 466-471. [CrossRef]

17. Hester, A.J.; Hobbs, R.J. Influence of fire and soil nutrients on native and non-native annuals at remnant vegetation edges in the Western Australian wheatbelt. J. Veg. Sci. 1992, 3, 101-108. [CrossRef]

18. Goldblum, D.; Beatty, S.W. Influence of an old field/forest edge on a Northeastern United States deciduous forest understory community. J. Torrey Bot. Soc. 1999, 126, 335-343. [CrossRef]

19. Phillips, O.L.; Rose, S.; Mendoza, A.M.; Vargas, P.N. Resilience of Southwestern Amazon forests to anthropogenic edge effects. Conserv. Biol. 2006, 20, 1698-1710. [CrossRef]

20. Ramirez, L.; Rada., F.; Llambı, L.D. Linking patterns and processes through ecosystem engineering: Effects of shrubs on microhabitat and water status of associated plants in the high tropical Andes. Plant Ecol. 2015, 216, 213-225.

21. Duncan, R.S.; Chapman, C.A. Seed dispersal and potential forest succession in abandoned agriculture in tropical Africa. Ecol. Appl. 1999, 9, 998-1008. [CrossRef]

22. Mucina, L.; Rutherford, M.C. The Vegetation of South Africa, Lesotho and Swaziland; Strelitzia 19; South African National Biodiversity Institute: Pretoria, South Africa, 2006.

23. Ruwanza, S.; Mulaudzi, D. Soil physico-chemical properties in Lapalala Wilderness old agricultural fields, Limpopo Province of South Africa. Appl. Ecol. Environ. Res. 2018, 16, 2475-2486. [CrossRef]

24. Midgley, D.C.; Pitman, W.V.; Middleton, B.J. A Guide to Surface Water Resources of South Africa; Water Research Commission: Johannesburg, South Africa, 1983.

25. Galatowitsch, S.; Richardson, D.M. Riparian scrub recovery after clearing of invasive alien trees in headwater streams of the Western Cape, South Africa. Biol. Conserv. 2005, 122, 509-521. [CrossRef]

26. Black, C.A. Methods of Soil Analysis: Part I Physical and Mineralogical Properties; American Society of Agronomy: Madison, WA, USA, 1965.

27. Chan, K.Y.; Bowman, A.; Oates, A. Oxidizible organic carbon fractions and soil quality changes in an Oxic Paleustalf under different pasture leys. Soil Sci. Soc. Am. J. 2001, 166, 61-67. [CrossRef] 
28. Bray, R.H.; Krutz, L.T. Determination of total, organic and available forms of phosphorus in soils. Soil Sci. 1945, 59, 39-45. [CrossRef]

29. Shannon, C.E.; Weaver, W. The Mathematical Theory of Communication; University of Illinois Press: Urbana, IL, USA, 1949.

30. Spellerberg, I.F.; Fedor, P.J. A tribute to Claude Shannon (1916-2001) and a plea for more rigorous use of species richness, species diversity and the 'Shannon-Wiener' Index. Glob. Ecol. Biogeogr. 2003, 12, 177-179. [CrossRef]

31. Zar, J.H. Biostatistical Analysis; Prentice Hall: London, UK, 1996.

32. Hurlbert, S. Pseudoreplication and the design of ecological field experiments. Ecol. Monogr. 1984, 54, 187-211. [CrossRef]

33. StatSoft, Inc. Statistica (Data Analysis Software System). Version 13.1. 2017. Available online: http: / / www.statsoft.com (accessed on 10 July 2018).

34. Šmilauer, P.; Lepš, J. Multivariate Analysis of Ecological Data Using Canoco 5, 2nd ed.; Cambridge University Press: Cambridge, UK, 2014.

35. Yao, J.; Holt, R.D.; Rich, P.M.; Marshall, W.S. Woody plant colonization in an experimentally fragmented landscape. Ecography 1999, 22, 715-728. [CrossRef]

36. Horn, A.; Krug, C.B.; Newton, I.P.; Esler, K.J. Specific edge effects in highly endangered Swartland Shale Renosterveld in the Cape Region. Ecol. Mediterr. 2011, 37, 63-74.

37. Cramer, V.A.; Hobbs, R.J. Old Fields: Dynamics and Restoration of Abandoned Farmland; Island Press: Washington, DC, USA; London, UK, 2007.

38. Mucina, L.; Bustamante-Sánchez, M.A.; Duguy, B.; Holmes, P.; Keeler-Wolf, T.; Armesto, J.J.; Dobrowolski, M.; Gaertner, M.; Smith-Ramírez, C.; Vilagrosa, A. Ecological restoration in mediterranean-type shrublands and woodlands. In Routledge Handbook of Ecological and Environmental Restoration; Allison, S., Murphy, S., Eds.; Taylor \& Francis: Abingdon, UK, 2017; pp. 173-196.

39. Cubina, A.; Aide, T.M. The effect of distance from forest edge on seed rain and soil seed bank in a tropical pasture. Biotropica 2001, 33, 260-267. [CrossRef]

40. Krug, C.B.; Krug, R.M. Restoration of old fields in Renosterveld: A case study in a Mediterranean type shrubland of South Africa. In Old Fields: Dynamics and Restoration of Abandoned Farmland; Cramer, V.A., Hobbs, R.J., Eds.; Island Press: Washington, DC, USA, 2007; pp. 265-285.

41. Donaldson, J.; Nänni, I.; Zachariades, C.; Kemper, J. Effects of fragmentation on pollinator diversity and plant reproductive success in renosterveld shrublands of South Africa. Conserv. Biol. 2002, 16, 1267-1276. [CrossRef]

42. Statton, J.; Gustin-Craig, S.; Dixon, K.W.; Kendrick, G.A. Edge effects along a seagrass margin result in an increased grazing risk on Posidonia australis transplants. PLoS ONE 2015, 10, e0137778. [CrossRef] [PubMed]

43. Hovel, K.A.; Regan, H.M. Using an individual-based model to examine the roles of habitat fragmentation and behavior on predator-prey relationships in seagrass landscapes. Landsc. Ecol. 2008, 23, 75-89. [CrossRef]

44. Sousa, W.P. The role of disturbance in natural communities. Annu. Rev. Ecol. Syst. 1984, 15, 353-391. [CrossRef]

45. Dohn, J.; Dembélé, F.; Karembé, M.; Moustakas, A.; Amévor, K.A.; Hanan, N.P. Tree effects on grass growth in savannas: Competition, facilitation and the stress-gradient hypothesis. J. Ecol. 2013, 101, 202-209. [CrossRef]

46. Penido, G.; Ribeiro, V.; Fortunato, D.S. Edge effect on post-dispersal artificial seed predation in the southeastern Amazonia. Braz. J. Biol. 2015, 75, 347-351. [CrossRef] [PubMed]

47. Normann, C.; Tscharntke, T.; Scherber, C. How forest edge-center transitions in the herb layer interact with beech dominance versus tree diversity. J. Plant Ecol. 2016, 9, 498-507. [CrossRef]

48. Piessens, K.; Honnay, O.; Devlaeminck, R.; Hermy, M. Biotic and abiotic edge effects in highly fragmented heathlands adjacent to cropland and forest. Agric. Ecosyst. Environ. 2006, 114, 335-342. [CrossRef]

49. Duncan, R.S.; Duncan, V.E. Forest succession and distance from forest edge in an afro-tropical grassland. Biotropica 2000, 32, 33-41. [CrossRef]

50. Wright, T.E.; Kasel, S.; Tausz, M.; Bennett, L.T. Edge microclimate of temperate woodlands as affected by adjoining land use. Agric. For. Meteorol. 2010, 150, 1138-1146. [CrossRef]

51. Ren, H.; Yang, L.; Liu, N. Nurse plant theory and its application in ecological restoration in lower subtropics of China. Prog. Nat. Sci. 2008, 18, 137-142. [CrossRef] 
52. Badano, E.I.; Samour-Nieva, O.R.; Flores, J.; Flores-Flores, J.L.; Flores-Cano, J.A.; Rodas-Ortíz, J.P. Facilitation by nurse plants contributes to vegetation recovery in human-disturbed desert ecosystems. J. Plant Ecol. 2016, 9, 485-497. [CrossRef]

53. Bever, J.D. Feedback between plants and their soil communities in an old field community. Ecology 1994, 75, 1965-1977. [CrossRef]

54. Dybzinski, R.; Fargione, J.E.; Zak, D.R.; Fornara, D.; Tilman, D. Soil fertility increases with plant species diversity in a long-term biodiversity experiment. Oecologia 2008, 158, 85-93. [CrossRef] [PubMed]

55. Wirth, R.; Meyer, S.T.; Leal, I.R.; Tabarelli, M. Plant herbivore interactions at the forest edge. Prog. Bot. 2008, 69, 423-448.

56. Zahawi, R.A.; Augspurger, C.K. Tropical forest restoration: Tree islands as recruitment foci in degraded lands of Honduras. Ecol. Appl. 2006, 16, 464-478. [CrossRef]

(C) 2018 by the author. Licensee MDPI, Basel, Switzerland. This article is an open access article distributed under the terms and conditions of the Creative Commons Attribution (CC BY) license (http://creativecommons.org/licenses/by/4.0/). 